\section{Wind turbine blades structure based on palm cellulose fibers composite material}

AbDerRaouf GHERISSI - Mechanical Engineering Department, College of Engineering, University of Tabuk, Saudi Arabia - a.gresi@ut.edu.sa

FAHD ALAHMARI - Mechanical Engineering Department, College of Engineering, University of Tabuk, Saudi Arabia - 361007560@stu.ut.edu.sa

MoнAmed FADHL - Mechanical Engineering Department, College of Engineering, University of Tabuk, Saudi Arabia =361000397@stu.ut.edu.sa

AdNAN ASIRI - Mechanical Engineering Department, College of Engineering, University of Tabuk, Saudi Arabia - 361000678@stu.ut.edu.sa

MESHAL ALHWITI - Mechanical Engineering Department, College of Engineering, University of Tabuk, Saudi Arabia - 361001250@stu.ut.edu.sa

OMAR ALAMRI - Mechanical Engineering Department, College of Engineering, University of Tabuk, Saudi Arabia - 341002032@stu.ut.edu.sa

Metab ALANISI - Mechanical Engineering Department, College of Engineering, University of Tabuk, Saudi Arabia - 361000981@stu.ut.edu.sa

IBRAHIM NASRI - Mechanical Engineering Department, College of Engineering, University of Tabuk, Saudi Arabia - ibrahimnasri2013@gmail.com

Érkezett: 2020. 11. 01. " Received: 01. 11. 2020. - https://doi.org/10.14382/epitoanyag-jsbcm.2021.16

\section{Abstract}

The uses of the cellulosic fibers in the natural fiber reinforced polymer composites (NFC) for constructing a wind turbine blade structure will be evaluated in the present work through experimental study. The blade shape designed according to the local wind characteristics on the Tabuk city in Saudi Arabia. The blade mechanical resistance identifies, according to the different forces applied to wind turbine blades. The palm cellulosic fibers were used as reinforcement. Those fibers were prepared through mechanical and chemical extraction process. The extraction was through mechanical decomposition in thin fibers and chemical extraction method by chloride and alkaline. To evaluate the reinforcement effect on wind turbine blades a horizontal wind turbine was constructed. The palm natural fibers used as reinforcement of blades with resinepoxy gives an encouraging result in the sense of robustness and efficiency. The uses of NFC based on cellulosic fibers for constructing wind turbine blades can be considered as a potential candidate for the manufacturing of total recycling wind turbine blades from natural fibers. Keywords: wind energy, wind turbine blades, palm cellulosic fibers, natural fiber composites (NFC) Kulcsszavak: szélenergia, szélturbina lapátok, pálma cellulózrostok, természetes rost kompozitok (NFC)
Abderraouf GHERISSI

Associate professor of mechanical engineering at the college of engineering at the University of Tabuk in Saudi Arabia

Fahd ALAHMARI mechanical engineering students at the college of ensineering at the University of Tabuk in Saudi

Mohamed FADHL mechanical engineering students at the college of engineering at the University of Tabuk in Saudi

Adnan ASIRI mechanical engineering students at the college of engineering at the University of Tabuk in Saudi

Meshal ALHWITI

mechanical engineering students at the college of engineering at the University of Tabuk in Saudi

Omar ALAMRI

mechanical engineering students at the college of engineering at the University of Tabuk in Saudi Arabia

Metab ALANISI mechanical engineering students at the college of engineering at the University of Tabuk in Saudi Arabia

Ibrahim NASRI Assistant professor of mechanical engineering at the college of engineering at the University of Tabuk in Saudi Arabia

\section{Introduction}

Several countries resort to the use of the renewable energies. The renewable energy power systems, such as solar panels and wind turbines produces fewer emissions than other power sources over their lifetime. In particularly wind turbines, which gives high efficiency in the presence of high wind flow and minimize the uses of fossil fuel and ameliorate the environment protection.

The installation and use of large numbers of wind turbines are one of the keys to increase the production of clean energy in the near future. Then the performances of such a wind turbine can be fulfilled only by using innovative, lightweight and highly durable composite materials such as glass, carbon and Kevlar fibers [1, 2].

The most important part of the wind turbine system, produced from composite material, is the wind turbine blade (WTB). The WTB is subjected to complex solicitations included combined impact, static and random cyclic loading. In order to reduce the different types of forces on WTB, it is recommended to build the wind blades from fiber reinforced polymer composites.
It is apparent that the currently most available solution for fiber reinforced composite is the use of E-glass/epoxy or carbon fiber composite [3]. But in the end life of WTB a recycling problematic will be created $[4,5]$. Then the solution for the recycling issue could be fulfilled by the use of recycled composite material. But it is required that this composite has a reinforcement can reach higher fracture and toughness resistance [6]. One of the existing solutions, is to use natural fiber composite (NFC) instead of carbon, Kevlar or glass fibers. The uses of NFC give important resistance to complex wind loading and are environmentally friendly and recyclable.

Blades are the most important composite part and the highest cost component of the wind turbines [7]. A wind turbine blades consists of two faces joined together and stiffened both by one or several integral webs linking the upper and lower parts of the blade shell or by a box spar with shell fairings [8]. For that reason, in this work to evaluate the blade structure made from NFC it is necessary, first, to identify the blade optimum structure and composite laying to withstand the wind solicitations. Secondly extract the cellulose palm fibers and then, construct the blades 
by hand lay-up molding. And finally, the experimental test was proposed to be conducted on horizontal wind turbine prototype constructed from three blades made from NFC.

\section{Materials and procedures}

In order to construct the blades (Fig. 1) and test the performance of NFC on horizontal axis wind turbine (HAWT) the blade structure was analyzed numerically and experimentally, see Fig. 2.

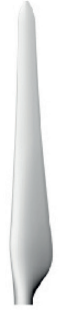

(a) Wind turbine blade

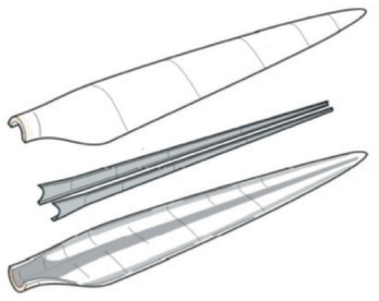

(b) Two aeroshells and the two shear webs
Fig. 1 The two aero-shells and the two shear webs of wind turbine blade [9] 1. ábra A szélturbina lapátjának két burkolata és nyíróöve [9]

\begin{tabular}{|c|c|}
\hline $\begin{array}{l}\text { Extract and characteriz } \\
\text { fibers. }\end{array}$ & the behavior of natural \\
\hline 1 & $\zeta$ \\
\hline \multicolumn{2}{|c|}{$\begin{array}{l}\text { Characterize the behavior of the NFC reinforced } \\
\text { wind turbine blade structure. }\end{array}$} \\
\hline 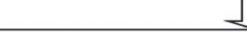 & $\zeta$ \\
\hline Conduct experimental & test in HAWT prototype \\
\hline
\end{tabular}

Fig. 2 Construction and evaluation of WTB made from NFC

2. ábra AzNFC-böl készült WTB felépitése és értékelése

\section{Characterization of the palm fibers (PF)}

The tensile test on palm fibers were conducted in Gant Universal Test Machine WP3, the average curve of the conducted tests is presented in Fig. 3 [9].

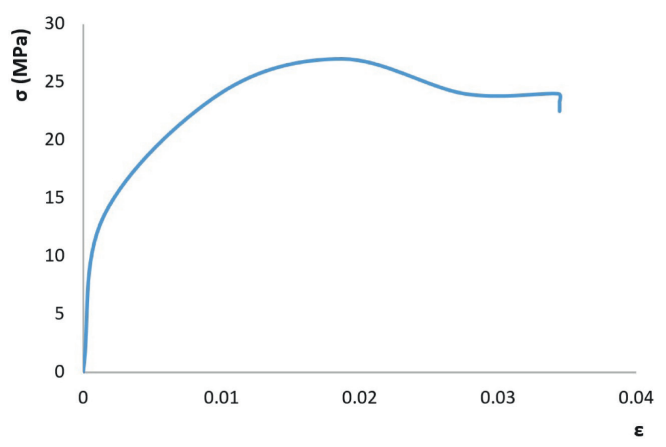

Fig. 3 Tensile test result of the palm fibers (PF) [9]

3. ábra A pálmarostok (PF) szakítóvizsgálati eredménye [9]

According to the Fig. 1 the ultimate tensile resistance of the $\mathrm{PF}$ is about $27 \mathrm{MPa}$, the maximum tensile strain at break is about $3.44 \%$ and the elastic modulus is about $8.96 \mathrm{GPa}$.

The present mechanical behavior is relatively weak compared with ordinary synthesized fibers usually uses in blade construction such as glass, kevlar and carbon fibers. Then it was necessary to stratify the composite in multi-layers with several fiber directions in order to bring an additional strength resistance to the blades.

\section{Principal solicitations in wind turbine blade}

The wind turbine blades consist of two faces joined together and stiffened both by one or several integral webs linking the upper and lower parts of the blade shell or by a box spar with shell fairings [7]. The flap wise load on wind turbines is caused by the wind pressure, and the edgewise load is caused by gravitational forces and torque load. Table 1 gather the solicitation needed to be overcomes during the construction of the blades.

\begin{tabular}{|c|c|}
\hline Blade part & Solicitation needed to overcame \\
\hline $\begin{array}{l}\text { The two external faces: } \\
\text { The upper part of the blade shell } \\
\text { The lower part of the blade shell }\end{array}$ & $\begin{array}{c}\text { Edgewise bending. } \\
\text { Cyclic tension-tension loads. } \\
\text { Cyclic compression -compression } \\
\text { loads }\end{array}$ \\
\hline The shear webs & Flap-wise bending \\
\hline The spar caps & Flap-wise bending \\
\hline The aero-shells & Elastic buckling \\
\hline $\begin{array}{l}\text { The leading and trailing edge } \\
\text { panels }\end{array}$ & $\begin{array}{l}\text { Bending moments associated with } \\
\text { the Gravitation loads }\end{array}$ \\
\hline $\begin{array}{c}\text { Table } 1 \text { Common solicitation in win } \\
\text { 1. táblázat Gyakori terhelések a szélturl }\end{array}$ & $\begin{array}{l}\text { Bending moments } \\
\text { associated with the } \\
\text { Gravitation loads }\end{array}$ \\
\hline
\end{tabular}

Wind direction

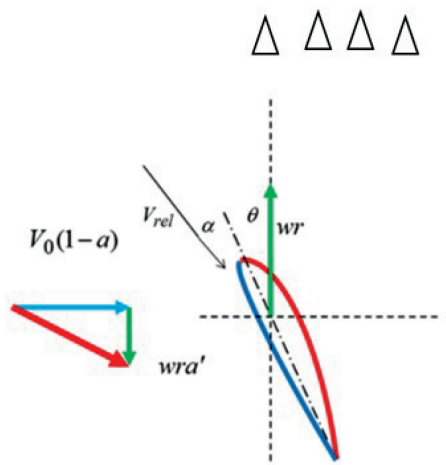

(a) Induced wind velocities

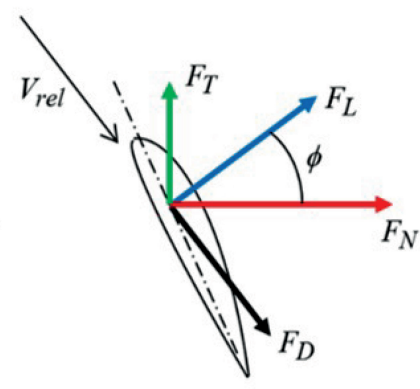

(b) Blade lift and drag forces/norma and tangential directions

\footnotetext{
Fig. 4 Representation of the zones of the blade solicitation and the blade induced velocity and forces [10]

4. ábra A penge terhelési zónáinak ábrázolása és a penge által kiváltott sebesség és erök [10]
}

The modelling of the wind turbine blades structure, starts by the identification of the applicable load case. For this study it was considered two cases of load at normal operation and at extreme wind loading, see Fig. 4. 
The vortex system induces on a wind turbine composed by an induced axial velocity and an induced tangential velocity component, see Fig. 4.

The induced axial velocity is specified as:

$V_{i a}=a \times V_{0}$

Where:

Vo: is the undisturbed wind speed.

$a$ : the axial induction factor

The induced tangential velocity is in the rotor wake is specified through as

$V_{i t}=2 a^{\prime} \omega r$

Where:

$a$ ' the tangential induction factor

$\omega$ denotes the angular velocity of the rotor

and $r$ is the radial distance from the rotational axis.

Since the wind flow does not rotate upstream of the rotor, the tangential induced velocity in the rotor plane is thus approximately $a$ ' $\omega r$.

If $a$ and $a$ ' are known, a 2-D equivalent angle of attack could be found based to the work of Martin O. L. Hansen [6] as follow:

The axial velocity specified as shown in Eq. (3)

$V_{a}=(1-a)$ Vo

The rotor velocity specified as shown in Eq. (4)

$V_{\text {rot }}=\left(1+a^{\prime}\right) \omega r$

The relative wind speed $V_{\text {rel }}$ has a flow angle direction $\phi$ :

$\phi=\alpha+\theta$

Where:

$\theta$ : The local twist angle of blade

$\alpha$ : The local angle of attack

Based to the Fig.4, the angle between wind speed and axial velocity, is the flow angle $\phi$ determined as shown in Eq. (6):

$\tan \phi=\frac{(1-a) V_{0}}{\left(1+a^{\prime}\right) \omega r}$

The lift and drag normal $F_{N}$ and tangential forces $F_{T}$ are determined as shown in Eq. (7) and Eq. (8) respectively:

$F_{N}=F_{L} \cos \phi+F_{D} \sin \phi$

$F_{T}=F_{L} \sin \phi-F_{D} \cos \phi$

Where:

$F_{L}:$ The lift force

$F_{D}$ : The drag force

The normal force coefficient $C_{N}$ and tangential force coefficient $C_{T}$ are shown in Eq. (9) and Eq. (10) respectively:

$C_{N}=C_{L} \cos \phi+C_{D} \sin \phi$

$C_{T}=C_{L} \sin \phi-C_{D} \cos \phi$

Where:

$C_{L}:$ The lift coefficient

$C_{D}:$ The drag coefficient

If the rotor solidity is introduced as $\sigma$ (see $E q$. (11)):

$\sigma(r)=\frac{c(r) B}{2 \pi r}$

Where:

$B$ : Number of blades

$C(r)$ : is the local chord

and $r$ is the radial position of the control volume
The uses of the momentum theory to connect the momentum changes in the air flowing through the turbine with the forces acting upon the blades, gives for normal forces as shown in Eq. (12):

$4 \pi r a=\frac{1}{2} B \frac{(1-a)}{\sin ^{2} \phi} c C_{N}$

Hence: $\frac{4 \sin ^{2} \phi}{\sigma C_{N}} a=1-a$

the momentum theory for Tangential forces gives:

$4 \pi r a^{\prime}=\frac{1}{2} B \frac{\left(1+a^{\prime}\right)}{\sin \phi \cos \phi} c C_{T}$

Where:

$B$ : the number of blades

$c$ : the local chord

$r$ : the radial position of the control volume

$C_{N}$ : the normal force coefficient

$C_{T}$ : the tangential force coefficient

Hence: $\frac{4 \sin \phi \cos \phi}{\sigma C_{T}} a^{\prime}=1+a^{\prime}$

These equations can be rearranged to give the axial and angular induction factors as a function of the flow angle (Eq. (16) and Eq. (17)).

Axial induction factor: $a=\frac{1}{\frac{4 \sin ^{2} \phi}{\sigma C_{N}}+1}$

Angular induction factor: $a^{\prime}=\frac{1}{\frac{4 \sin \phi \cos \phi}{\sigma C_{T}}-1}$

The normal force $F_{N}$ causes a "flapwise" bending moment at the root of the blade as shown in Eq. (18):

$M_{N}=\int_{r_{\min }}^{R} F_{N}\left(r-r_{\min }\right) d r$

Where:

$r$ : the local radius

$r_{\text {min }}:$ the local minimum radius

$R$ : the total radius of the rotor

$d r$ : the incremental part of the blade

The tangential force $F_{T}$ causes a tangential bending moment $M_{T}$ at the root of the blade shown in Eq. (19):

$M_{T}=\int_{r_{\min }}^{R} F_{T}\left(r-r_{\min }\right) d r$

If neglect the relatively small twist of the blade cross section and assume that these bending moments are aligned with the principal axes of the blade structural cross section.

The maximum tensile stress due to aerodynamic loading is therefore given by Eq. (20):

$\sigma_{\text {max }, \text { aero }}=\frac{M_{N}}{I_{T T}} \frac{d_{o}}{2}+\frac{M_{T}}{I_{N N}} \frac{b}{2}$

Where:

$M_{N}$ : flapwise bending moment

$M_{T}$ : tangential bending moment

$I_{T T}$ : tangential moment of inertia

$I_{N N}:$ moment of inertia about the flapwise

$d_{0}$ : length of the blade

$b$ : the flapwise length 
Consider equilibrium of element of blade, see Fig. 5 then:

$\frac{d F_{c}}{d r}=-m(r) \omega^{2} r$

Where:

$m(r)$ is the mass of the blade per unit length

$d F c$ is the incremental centrifugal force

$\omega$ is the angular velocity
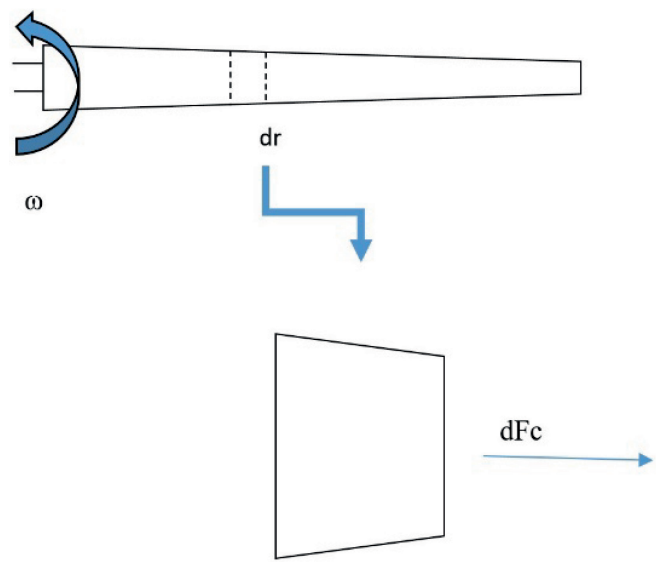

Fig. 5 Element of blade

5. ábra A penge egy eleme

Then, the rotor solidity can be written as:

$\sigma_{c}=\frac{F_{c}(r)}{A(r)}$

Where, $A(r)$ is the local area at the blade element

In the other hand, the bending moment at the blade root due to self-weight loading can dominate the stresses at the blade root. The bending moment is a cyclic load with a frequency of $f=\omega / 2 \pi$. The maximum self-weight bending moment occurs when a blade is horizontal, see Fig. 6 .

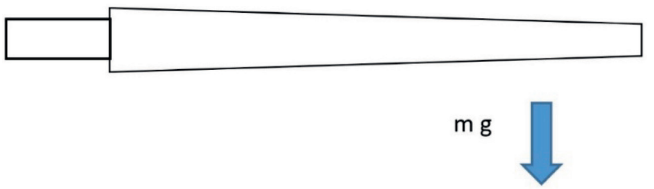

Fig. 6 Blade self-weight

6. ábra Penge önsúlyának figyelembe vétele

The maximum self-weight bending moment could written as shown in Eq. (23), and this is a tangential (edge-wise) bending moment.

$M_{s w}=\int_{r_{\min }}^{R} m(r) g\left(r-r_{\min }\right) d r$

Therefore, the maximum bending stress due to self-weight is given by Eq. (24):

$\sigma_{\max , s w}=\frac{M_{s w}}{I_{N N}} \frac{b}{2}$

Finally, the whole Combined Loading could be written as shown in Eq. (25):

$\sigma_{\max }=\sigma_{\max , \text { aero }}+\sigma_{c}+\sigma_{\max , s w}$
According to the Eq. (25), it is necessary to conduct a calculation on the combined load of the whole blade structure, in order to fix the dimensions and select the composite structure that could withstand the combined load. For that reason, a FE modelling it was conducted in previous work [8].

\section{Construction of the blades and test of the wind turbine}

The composite should withstand essentially to the complex loading of the wind. The natural fibers were selected, extracted and treated to prevent any rapid degradation due to existing of water or any other non-desired constituent. A strafed multi-layer layup composite was choosing to withstand combined load, see Fig. 7.

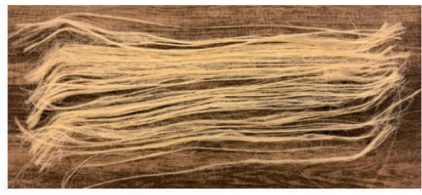

(a)

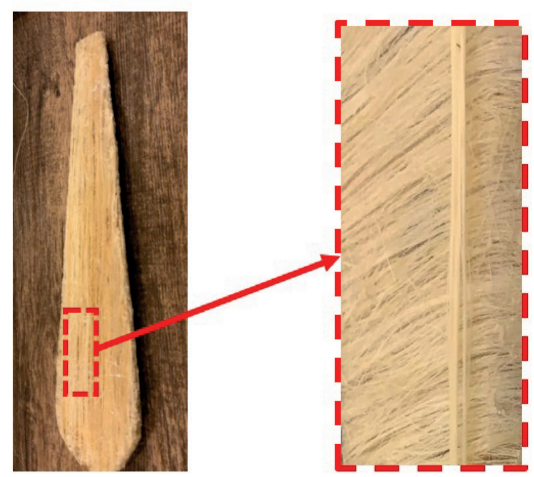

(b)

Fig. 7 (a) The extracted Long Palm fibers (b) the construction of the blades from palm natural fibers and resin epoxy

7. ábra (a) A kivont hosszú pálma szálak b) a pengék felépitése természetes pálma szálakból és epoxy gyantából

The wind blade prototype was constructed as shown in Fig. 8 , with a total length $4400 \mathrm{~mm}$ a maximum width $400 \mathrm{~mm}$, the shape was selected with zero airfoil twist angle to prevent any additional vortex and fatigue to the blade structure, see Fig. 8.
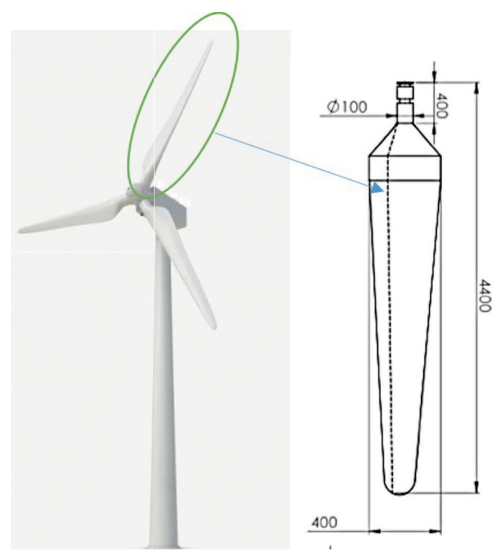

Fig. 8 The blade's dimensions (all dimensions in millimeter)

8. ábra A penge méretei (milliméterben) 


\section{Results and discussion}

All experimental tests were obtained at the month of April 2020, the test were conducted on the wind turbine prototype shown in Fig. 9. The test of the wind turbine performance was executed at several wind conditions as shown in the Table 2. The maximum wind speed is about $25 \mathrm{~km} / \mathrm{h}$ and the minimum speed about $5 \mathrm{~km} / \mathrm{h}$.

The optimum pitch angle was identifying through the determination of the wind direction and the maximum experimental rotational speed of the rotor. The actual measured power was calculated as an input mechanical power without generation of electricity.
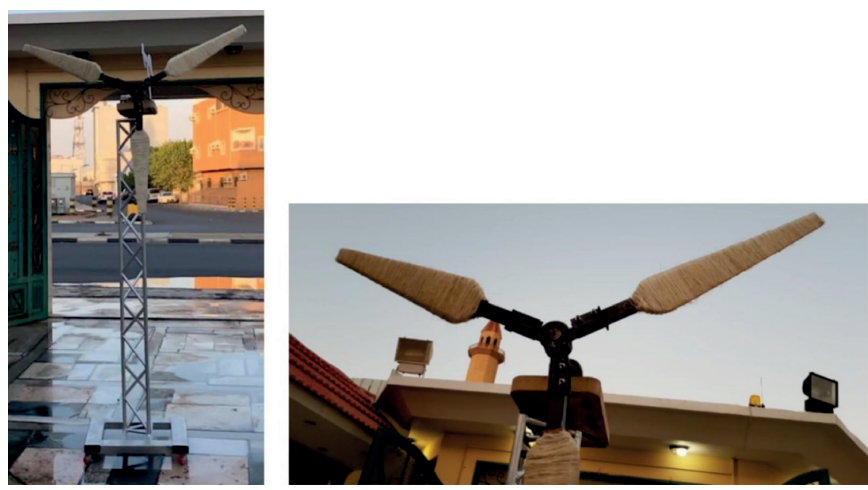

Fig. 9 The wind turbine prototype

9. ábra A szélturbina prototípusa

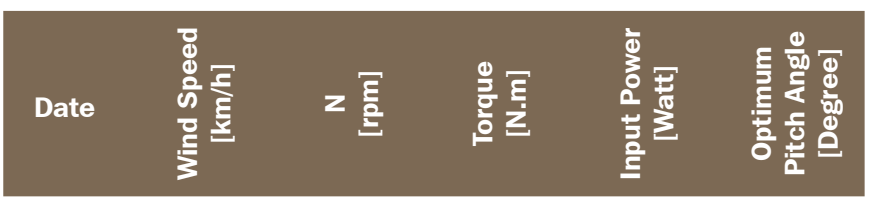

\begin{tabular}{lccccc} 
7-Apr & 14 & 10 & 9.8 & 10 & 15 \\
\hline 8-Apr & 7 & 5 & 9.8 & 5.1 & 5 \\
\hline 9-Apr & 22 & 14 & 9.8 & 14 & 22 \\
\hline 10-Apr & 14 & 10 & 9.8 & 10 & 15 \\
\hline 11-Apr & 18 & 12 & 9.8 & 12 & 20 \\
\hline 12-Apr & 15 & 10 & 9.8 & 10 & 15 \\
\hline 13-Apr & 25 & 18 & 9.8 & 18 & 24
\end{tabular}

Table 2 Test of the wind turbine at several wind conditions

2. táblázat A szélturbina vizsgálata többféle szélviszony mellett

The change in power versus the rotation speed of the wind turbine is shown in the Fig. 10.

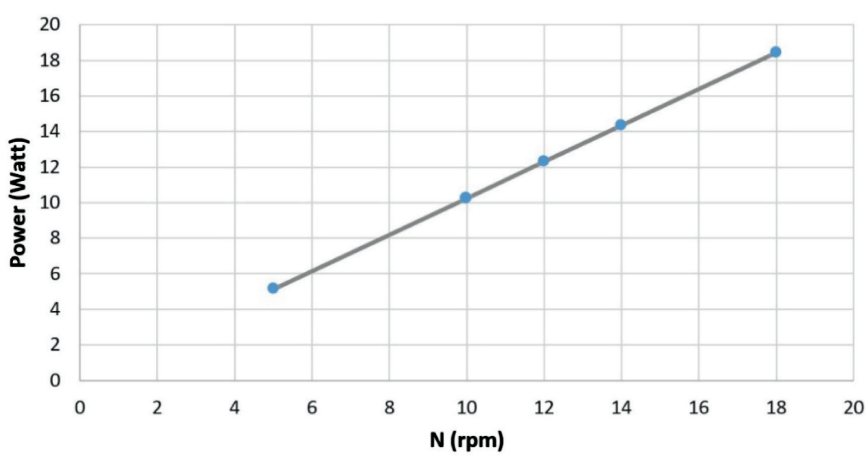

Fig. 10 The change of power according to the rotation speed of the wind turbine. 10. ábra A teljesitményváltozás a szélturbina forgási sebessége szerint.
The change in power versus the wind speed is shown in the Fig. 11.

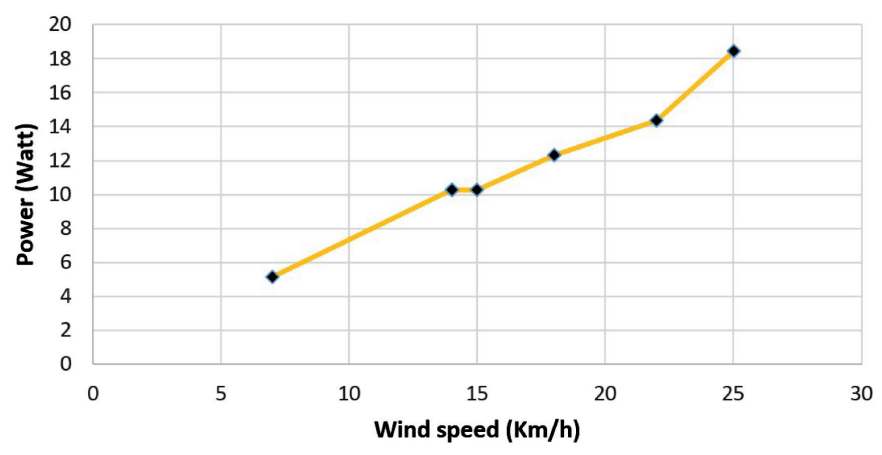

Fig. 11 The change of power versus the wind speed

11. ábra A teljesítményváltozás a szélsebesség függvényében

The influence of wind speed vs the rotation speed of the wind turbine is shown in the Fig. 12.

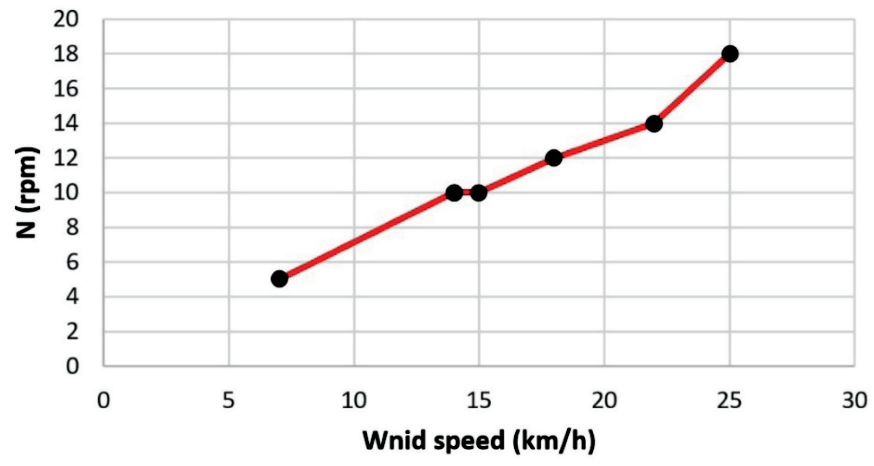

Fig. 12 The change in wind turbine rotation speed versus the wind speed

12. ábra A szélturbina forgási sebességének változása a szélsebességhez viszonyítva

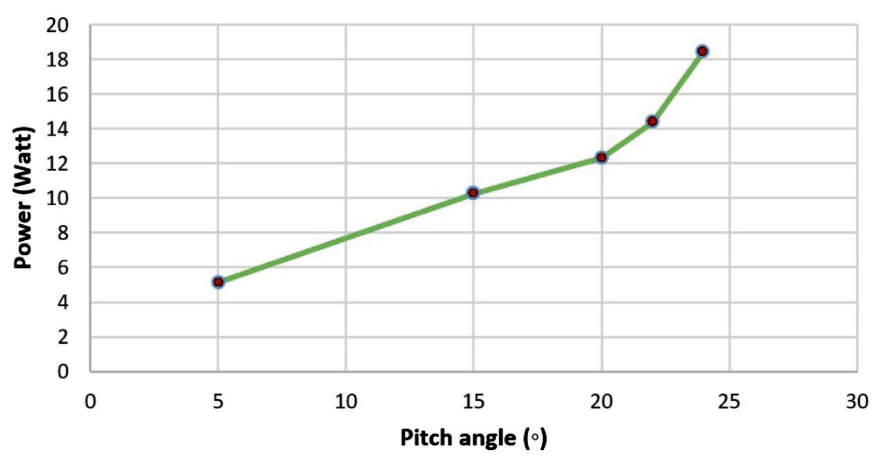

Fig.13 The change in power according to the blade pitch angle 13. ábra A teljesítményváltozás a penge dölésszöge szerint

The variation of pitch angle could increase the input power of the wind turbine, see Fig. 13.

The observed tests and results shows that the power increases linearly with the rotation speed and wind speed, the power could reach 18 Watt. As well as, the change of the blade pitch angle influence positively the input power of the wind turbine.

Also it was observed that, at slow wind speed $v=7 \mathrm{~km} / \mathrm{h}$ the wind turbine gives a power about 5 Watt, due to light weight of wind blades. The blade structure was tests at several wind conditions and the structure is remaining stable and the composite withstand climatic severe conditions without any damage. 


\section{Conclusions}

Small wind turbine applications are now becoming a solution for producing alternative energy. Actually, as the cost of small wind turbines drops through mass production and technical developments, and as the fee of electrical energy rises, mounting small wind turbines in windy sites will become progressively sustainable. However, the end life of wind turbine and wind turbine blades will challenge the society to a huge waste volume of no recycling material. Then, in the present investigation, the solution was to use natural palm fibers $(\mathrm{PF})$ instead of glass fiber, Kevlar and carbon fiber.

The experimental tests and results on wind turbine made from $\mathrm{PF}$, indicates that the power increases linearly with the rotation speed and wind speed, the power could reach 18 Watt. As well as, the change of the blade pitch angle influence positively the input power of the wind turbine.

Also, it was observed that, at slow wind speed $v=7 \mathrm{~km} / \mathrm{h}$ the wind turbine gives power about 5 Watt, due to the light weight of wind blades, which represent a great advantage compared with the heavy classic wind turbines. The blade structure was tested at several wind conditions and the structure is remaining stable and the composite withstand climatic severe conditions without any damage. The palm natural fibers used as reinforcement of blades with resin, epoxy gives an encouraging result in the sense of robustness and efficiency.

The palm fibers have proved an excellent mechanical properties and are available free of charge in the Tabuk region in Saudi Arabia. Also near to Tabuk city a significant high continues wind speed, especially in the Neom region, where the wind speed could provide high input power to the wind turbines. The uses of NFC based on cellulosic fibers for constructing wind turbine blades can be considered as a potential candidate for the manufacturing of total recycling wind turbine blades from natural fibers.

\section{Funding}

This research was funded by [Deanship of scientific Research at The University of Tabuk, Saudi Arabia] grant number [s1440-0180]

\section{Acknowledgments}

The author acknowledge the financial support provided by the Deanship of Scientific Research (DSR) at University of Tabuk, Tabuk, Saudi Arabia, under grant No. s-1440-0180.

\section{Conflicts of Interest}

The authors declare no conflict of interest.

\section{References}

[1] Boyano, A.; Lopez-Guede, J.M.; Torre-Tojal, L.; Fernandez-Gamiz, U.; Zulueta, E.; Mujika, F. Delamination Fracture Behavior of Unidirectional Carbon Reinforced Composites Applied to Wind Turbine Blades. Materials 2021, 14, 593. https://doi.org/10.3390/ma14030593

[2] Souad A. M. AlBat'hi 1, a, Yose Fachmi Buys 1, Muhammad Hazwan Hadzari 1 Maizatulnisa Othman, A Light Material for Wind Turbine Blades, Advanced Materials Research Vol 1115 ,2015, pp 308-313; https://doi.org/10.4028/www.scientific.net/AMR.1115.308

[3] K. L. Pickering, M.G. Aruan Efendy, T.M. Le, A review of recent developments in natural fibre composites and their mechanical performance, Composites: Part A 83, 2016, 98-112; https://doi.org/10.1016/j.compositesa.2015.08.038

[4] Beauson J., Brøndsted P., Wind Turbine Blades: An End of Life Perspective. In: Ostachowicz W., McGugan M., Schröder-Hinrichs JU., Luczak M. (eds) MARE-WINT. Springer, Cham.,2016 https://doi.org/10.1007/978-3-319-39095-6_23

[5] Constantinos S. Psomopoulos, Konstantinos Kalkanis, Stavros Kaminaris, George Ch. Ioannidis and Pavlos Pachos A Review of the Potential for the Recovery of Wind Turbine Blade Waste Materials Recycling 2019, 4, 7; https://doi.org/10.3390/recycling 4010007

[6] Leon Mishnaevsky Jr., Kim Branner, Helga Nørgaard Petersen, Justine Beauson, Malcolm McGugan and Bent F. Sørensen, Materials for Wind Turbine Blades: An Overview, Materials 2017, 10, 1285; https://doi.org/10.3390/ma10111285

[7] Brøndsted P, Nijssen R. (Eds.) Advances in Wind Turbine Blade Design and Materials; Woodhead Publishing, Oxford, UK, 2013; ISBN 978-085709-426-1

[8] Martin O. L. Hansen, Aerodynamics of Wind Turbines, 2nd ed. Earthscan 2008; ISBN 9781844074389

[9] Abderraouf GHERISSI, Faris SHUREDYA, Emad ALATAWI Abdulrahman ALBALAWI, Bareq ALBALAWI, Sustainable Investigation On Thermoforming Of Cellulose Fibers Composites, Technical University Of Cluj-Napoca Acta Technica Napocensis Series: Applied Mathematics, Mechanics, and Engineering Vol. 62, Issue IV, November, 2019, p583-588; ISSN 2393-2988

[10] Abderraouf GHERISSI, A Study of Wind Turbine Blade Structure Based on Cellulose Fibers Composite Material, International Conference on Green Energy \& Environmental Engineering, Proceedings of Engineering and Technology - PET, 2018, Vol 38, P80 - P85; ISSN 2356-5608

Ref.:

Gherissi, Abderraouf - Alahmari, Fahd - Fadhl, Mohamed - Asiri, Adnan - Alhwiti, Meshal - Alamri, Omar - Alanisi, Metab - Nasri, Ibrahim: Wind turbine blades structure based on palm cellulose fibers composite material Építőanyag - Journal of Silicate Based and Composite Materials, Vol. 73, No. 3 (2021), 109-114. p. https://doi.org/10.14382/epitoanyag-jsbcm.2021.16

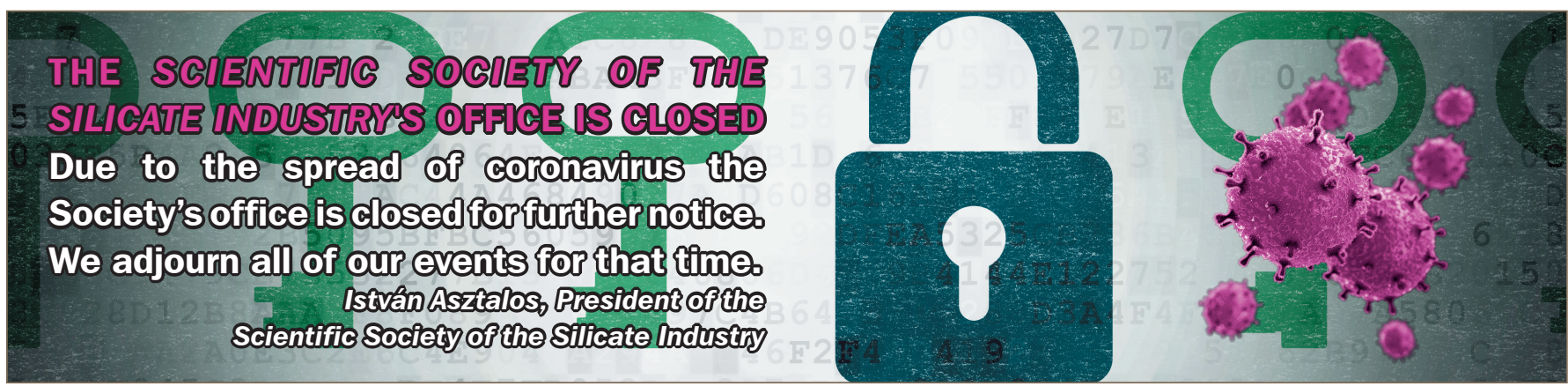

